DOI: https://doi.org/10.12797/Politeja.15.2018.53.06

\title{
Michał LUBINA
}

Uniwersytet Jagielloński w Krakowie michal.lubina@uj.edu.pl

\section{NIE TYLKO GEOPOLITYKA}

\section{RELACJE ROSYJSKO-CHIŃSKIE POD KONIEC DRUGIEJ DEKADY XXI WIEKU}

ABSTRACT Beyond geopolitics. The Sino-Russian relations in the late 2010s

Since more than a decade the international (Western) academia has been considering Sino-Russian relations as an „Axis of Convenience”: a temporarily, shallow, tactical alliance prone to changing circumstances; a one that may turn into antagonism should international situation evolve. This approach reached its climax after Donald Trump's victory in US Presidential elections in 2016: many believed that there would soon be „a reverse Nixon's strategy”. The reality has falsified these theses and showed that Sino-Russian relations have solid foundations. These more stable base of Russia-China relations was born in late 2000s when Russian ruling elite made a choice and decided that China did not pose a threat to current Russian regime. This elite's understanding paved a way for current Sino-Russian rapprochement.

Key words: Russia, China, Sino-Russian relations, Axis of Convenience, realism in international relations, constructivism in international relations

Słowa kluczowe: Rosja, Chiny, stosunki rosyjsko-chińskie, oś wygody, realizm w stosunkach międzynarodowych, konstruktywizm w stosunkach międzynarodowych 
$\mathrm{W}$ brew oczekiwaniom i głosom wielu zwycięstwo Donalda Trumpa w amerykańskich wyborach prezydenckich nie doprowadziło do „odwróconego manewru Nixona” i nie osłabiło relacji rosyjsko-chińskich. Udowodniło za to, że stosunki Moskwy i Pekinu są czymś więcej niż tylko geopolityczną „osią wygody”, podatną na zmienną koniunkturę międzynarodową. Stało się tak, gdyż trwające od początku drugiej dekady XXI w. zbliżenie na linii Moskwa-Pekin wzięło swój początek w decyzji rosyjskich elit politycznych, które uznały, iż Chiny im nie zagrażają.

\section{WSTĘP. REALIZM I KONSTRUKTYWIZM W BADANIACH RELACJI ROSYJSKO-CHIŃSKICH}

W nauce międzynarodowej (zachodniej) o stosunkach rosyjsko-chińskich (neo) realizm pozostaje dominującą szkołą. Jest tak przynajmniej od 2008 r., kiedy została opublikowana klasyczna już praca australijskiego badacza Bobo Lo zatytułowana The Axis of Convenience. Według Lo owa rosyjsko-chińska „oś wygody” oparta na interesach, nie zaś na ideologii, łączy taktyczny oportunizm z kalkulacjami strategicznymi, nie jest jednak osia. w sensie wojskowo-politycznego sojuszu z powodu zbyt wielu sprzeczności; jest to oś zrodzona z konieczności, a nie naturalnego ciążenia $i$ dziata, gdyż relacje rosyjsko-chinskie oparte sa na oportunizmie, pragmatyzmie i niematym stopniu cynizmu [...] w najbardziej prymitywnej formie sa to „anty-relacje” oparte na potrzebie neutralizowania i negowania (Zachodu $)^{1}$. Pogląd ten wskazuje, że obu państwom z przyczyn wewnętrznych i zewnętrznych opłaca się utrzymywać dobre relacje. Z punktu widzenia Rosji dobre stosunki z Chinami zwiększają bezpieczeństwo rosyjskiego Dalekiego Wschodu, zgodnie z zasadą „żyj blisko z przyjaciółmi i jeszcze bliżej z wrogami”, oraz zaspokajają ambicje globalne 2 . Przyjazne stosunki z Rosją zabezpieczają północną flankę Chin, dzięki czemu kraj ten nie musi martwić się o kwestie bezpieczeństwa i może skoncentrować się na ważniejszych sprawach, takich jak Tajwan, Morze Południowochińskie czy relacje ze Stanami Zjednoczonymi. Chociaż dla Chin Rosja jest partnerem istotnym, to jednak drugorzędnym: chińskie spojrzenie na Rosje tączy wzniostość Państwa Środka, pragmatyzm i cynizm ${ }^{3}$. Podsumowaniem tez Bobo Lo jest twierdzenie, że relacje rosyjsko-chińskie są ograniczone i podatne na zmienne koleje losów relacji rosyjsko-amerykańskich i chińsko-amerykańskich.

Perspektywę neorealistyczną odwołującą się do pracy Bobo Lo przyjmuje większość badaczy zachodnich, głoszących, że współpraca rosyjsko-chińska jest pragmatyczna i oportunistyczna: prawdziwa, lecz ptytka . Mimo iż wśród specjalistów rosyjskich

1 Bobo Lo, The Axis of Convenience. Moscow, Beijing, and the New Geopolitics, London-New York 2008, s. 3-44, 54-55 i 131.

2 Tamże, s. 3-44.

3 Tamże, s. 3.

4 L. Jakobsen i in., China's Energy and Security Relations with Russia. Hopes, Frustrations and Uncertainties, „SIPRI Policy Paper” 2011, nr 29, s. 3-5; inne ujęcia w tym nurcie przedstawiają m.in. J.L. Wilson, Strategic Partners. Russian-Chinese Relations in the Post-Soviet Era, London 2004; The Future of 
i chińskich dominuje pozytywne, afirmatywne spojrzenie na relacje Moskwy i Pekinu (zgodnie z oficjalną linią obu krajów), to zachodni sceptycyzm i pesymizm odnośnie do tych relacji podzielają również niektórzy badacze rosyjscy i chińscy. Np. Dmitrij Trienin pisze, że na szczytach rosyjsko-chińskich nie ma ducha koleżenstwa: szczyty sa bardzo biznesowe [...] w oficjalnych kontaktach grzeczność jest norma, szczerość rzadkościa; dodaje wszakże, że Chińczycy bardzo dbają o to, żeby nie irytować Rosji, by ta nie stała się zbyt agresywna wobec Chin ${ }^{5}$. Minxin Pei określa zaś relacje rosyjsko-chińskie mianem jednocześnie przyjaźni i wrogości ${ }^{6}$.

Trzeba przyznać, że są solidne podstawy do patrzenia na relacje rosyjsko-chińskie przez pryzmat realistyczny. Oba te państwa prowadzą politykę zagraniczną w duchu realistycznym, ich elity polityczne wychowały się $\mathrm{w}$ realistycznej kulturze strategicznej i zgodnie odrzucają pretensje liberalizmu do twierdzeń, że takie procesy, jak globalizacja, demokratyzacja czy rozwój międzynarodowych instytucji zwiększyły szansę na trwały pokój międzynarodowy. Rosjanie i Chińczycy większej trwałości upatrują raczej w mechanizmach równoważenia się państw w duchu dziewiętnastowiecznego koncertu mocarstw ${ }^{7}$. Moskwa zgadza się z Pekinem w kwestii percepcji polityki międzynarodowej (świat oparty na walce o potęgę z jednym, acz słabnącym hegemonem $)^{8}$ oraz w sprawie zasad, na których powinno być oparte funkcjonowanie współczesnego świata (nieinterwencja, suwerenność itp.).

Szczególnie Rosjanie są przywiązani do realizmu politycznego i do traktowania działań innych głównie przez pryzmat geopolityczny9. W światopoglądzie obecnej ekipy kremlowskiej międzynarodowa polityka „ma charakter ponadczasowy” i oparta jest na Leninowskiej zasadzie „kto kogo” i (neo) Hobbesowskiej wizji, w której dominuje siła, wygrywają potężni, a słabi są bici - polegać więc trzeba przede wszystkim na sobie i swoim potencjale ${ }^{10}$. Chińczycy również są realistami ${ }^{11}$, acz odmiennymi: zakorzenionymi we własnej historii i jej wzorcach ${ }^{12}$, w wyrastającej z wielowiekowej tradycji kulturze strategicznej ${ }^{13}$. Kanony te po konfucjańsku podkreślają moralne cechy

China-Russia Relations, red. J. Ballacqua, Kentucky 2010; Rapprochement or Rivalry? Russia-China Relations in a Changing Asia, red. S.W. Garnett, Washington D.C. 2000.

5 А. Тренин, Верньце друзья? Как Россия и Китай воспринимают друг друга, Carnegie Moscow Center, 1 VI 2012, s. 20, [online] https://carnegieendowment.org/files/CER_TreninRuss_web.pdf, $28 \mathrm{~V}$ 2018.

6 Minxin Pei, China and Russia: Best Frenemies Forever?, „Fortune” 2013, 28 III.

7 Co widać w publikowanych regularnie „wspólnych oświadczeniach”, np. Совместнал deкларащия Российской Федераиии и Китайской Народной Республики, 2 XII 2002, [online] www.mid.ru, 25 V 2018; Совместнал декларация Российской Федерации и Китайской Народной Республики, [w:] Сборник российско-китайских договоров 1949-1999, Москва 2000, s. 333-337.

8 Yan Xuetong i in., Ancient Chinese Thought, Modern Chinese Power, Princeton 2010, s. 199-223, 229-252 .

9 M. Kaczmarski, Rosja na rozdrożu. Polityka zagraniczna Wtadimira Putina, Warszawa 2006, s. 168. 
przywództwa ${ }^{14} \mathrm{i}$ chińską unikatowość ${ }^{15}$. Chociaż są oczywiste różnice w rozumieniu realizmu politycznego w Chinach i realizmu na Zachodzie i w Rosji ${ }^{16}$, to przy wszystkich tych odmiennościach chińska polityka również może zostać uznana za realistyczną dlatego też realistyczne spojrzenie na relacje rosyjsko-chińskiej wydaje się być niejako naturalne. Nie jest to wszakże jedyna perspektywa.

Realistyczne założenia kwestionują badacze z nurtu konstruktywistycznego. Według nich stosunki rosyjsko-chińskie to coś więcej niż drugorzędna oś wygody zdominowana przez strach, nieufność $i$ brak zaufania, gdyż jeśli wygodę zdefiniuje sie jako pragmatyczne realizowanie interesów, to dojdzie się do istoty funkcjonowania panstwa: relacje rosyjsko-chińskie to nieuświęcone sakramentalnie matżeństwo ${ }^{17}$. Z pesymistyczną, realistyczną zachodnią wizją stosunków rosyjsko-chińskich walczą badacze rosyjscy ${ }^{18}$ oraz chińscy (np. Fu Ying) ${ }^{19}$. Aleksander Gabujew pisze, że Moskwa i Pekin są partnerami ze strategicznymi korzyściami: podkreśla, że stosunki rosyjsko-chińskie są przykładem, jak nawet oportunistyczna i taktyczna współpraca nie-zachodnich mocarstw podkopuje (zachodni) międzynarodowy porządek ${ }^{20}$. Piszący z bardzo chińskim dystansem do bieżących spraw Yu Bin podkreśla, że częste nieporozumienia lub nawet sprzeczności nie wpływają na ogólnie dobry nastrój relacji rosyjsko -chińskich: tymczasowa niezdolność do zakończenia rozmów w określonych kwestiach lub trudność w wdrożeniu czegoś nie wstrzasa podstawami relacji21.

Zdaniem Marcina Kaczmarskiego, który sformułował najbardziej znaczącą, konstruktywistyczną odpowiedź na dominację realizmu w spojrzeniu na stosunki

14 Yan Xuetong, Shijie quanli de zhuanyi. Zhengzhi lingdao yu zhanlue jingzheng (The Transition of World Power. Political Leadership and Strategic Competition), Beijing 2015; Yufan Huang, Q. \& A.: Yan Xuetong Urges China to Adopt a More Assertive Foreign Policy, „The New York Times” 2016, 9 II.

15 Qin Yaqing on Rules vs Relations, Drinking Coffee and Tea, and a Chinese Approach to Global Governance „Theory Talk \#45”, [online] https://www.files.ethz.ch/isn/155106/Theory\%20Talk45_ Yaqing.pdf., 26 V 2018.

16 Zheng Yongnian, Preface, [w:] China and International Relations. The Chinese View and the Contribution of Wang Gungwu, London 2010, s. xiii; J.C. Hsiung, A Re-Appraisal of Abrahamic Values and Neorealist IR theory. From a Confucian-Asian Perspective, [w:] tamże, s. 18; G. Rozman, The Sino-Russian Challenge to the World Order. National Identities, Bilateral Relations, and East Versus West in the 2010s, Stanford 2014, s. 64.

17 R.C. Nation, Russia in East Asia. Aspirations and Limitations, [w:] Russia's Prospects in Asia, red. S. Blank, Strategic Studies Institute 2010, s. 38-41.

18 А.В. Аукин, От нормализачии к стратегическому партнерству. Россия и Китай после распада СССР, [w:] Россия и Китай: четьре века взаимодействия. История, современное состолние u перспективы развития российско-китайских отномений, Москва 2013, s. 229-409.

19 Fu Ying, How China Sees Russia. Beijing and Moscow Are Close, but Not Allies, „Foreign Policy” 2015, 14 XII.

20 A. Gabuev, China and Russia. Friends With Strategic Benefits, Carnegie Moscow Center, 7 IV 2017, [online] http://carnegie.ru/2017/04/07/china-and-russia-friends-with-strategic-benefits-pub-68628, 25 V 2018.

21 Yu Bin, Politics of „Reluctant Allies”, „Comparative Connections” 2016, vol. 18, nr 2, [online] http:// cc.csis.org/2016/09/politics-reluctant-allies/, 26 V 2018. 
rosyjsko-chińskie, kryzys 2008 r. i jego następstwa podważyły logikę polityki siły w relacjach rosyjsko-chińskich: zamiast doprowadzić do napięć, osłabienia relacji bądź nawet konfliktu, kryzys zbliżył Moskwę i Pekin do siebie, a ich współpraca zintensyfikowała się i objęła nowe obszary. To nie tylko pogłębiło przewagę Pekinu, zasygnalizowało zaprzestanie przez Rosję prób równoważenia Chin i pogodzenie się z chińską przewagą, lecz przede wszystkim zmienito relacje rosyjsko-chińskie na tyle, iż nie można już mówić tylko i wytacznie o "geopolitycznej wygodzie” [...] analiza stosunków rosyjsko-chinskich tylko pod katem strategicznej interakcji, geopolitycznej odpowiedzi na dziatania USA lub projekcji sity jest niewystarczajaca: nie wyjaśnia, jak Moskwa i Pekin porozumiaty się wobec znaczacej nierównowagi sit; zatożenia Realpolitik nie ttumacza, dlaczego Rosja wybrata adaptacje do nowej sytuacji, nowego rozdania sity materialnej, ani nie ttumacza, dlaczego Chiny zdecydowaty się na okazanie strategicznej cierpliwości wobec swego sasiada ${ }^{22}$.

Według tej narracji najważniejszą przyczyną zachowań rosyjskich jest percepcja Chin przez elity rosyjskie. Chiny zdały się przekonać Kreml o swoich przyjaznych intencjach przez okazywanie powściągliwości w swojej polityce wobec Rosji. Chiny powstrzymują się od wykorzystywania swojej przewagi ekonomicznej, by uzyskać ustępstwa polityczne od Moskwy, co spotyka się ze zrozumieniem i wdzięcznością elit rosyjskich ${ }^{23}$. Konstruktywistyczną narrację można podsumować stwierdzeniem, że Rosja, chcąc nie chcąc, pogodziła się z chińską dominacją i stara się w tej sytuacji uzyskać jak najwięcej korzyści dla interesów rosyjskich.

\section{ROSYJSKIE ELITY A CHINY}

Zważywszy na strukturę władzy w Rosji, gdzie od czasów objęcia władzy przez Władimira Putina w 2000 r. doszło do znaczącej modyfikacji (na początku swoich rządów Putin był primus inter pares, obecnie jest niekwestionowanym przywódcą, który podejmuje wszystkie najważniejsze decyzje $)^{24}$, osobisty stosunek Putina do Chin ma ogromne znaczenie. Wynika to z faktu, że Putin, byty oficer wywiadu, przyktada ogromna role do indywidualnej dyplomacji, preferując opieranie się na przyjacielskich relacjach z innymi przywódcami w celu zbudowania silnych relacji państwowych ${ }^{25}$. W przypadku Chin gdzie, nawiasem mówiąc, Putin jest bardzo popularny ${ }^{26}$ - ten czynnik osobisty zadziałał szczególnie silnie od momentu dojścia do władzy Xi Jinpinga (2013 r.). Putin i Xi ponoć darzą się sympatią i mają bardzo dobre relacje osobiste ${ }^{27}$ : rosyjski przywódca

\footnotetext{
22 M. Kaczmarski, Russia-China Relations in the Post-Crisis International Order, London 2015, s. 3-8.

23 Tamże, s. 169.

24 Bobo Lo, Russia and The New..., s. 7.

25 A. Gabuev, China's Pivot to Putin's Friends, „Foreign Affairs” 2016, 25 VI.

26 «Китайць понимают, что Россия деградирует из-за коррупции и неэффективного управления», Lenta.ru, 30 IV 2015 [online] https://carnegie.ru/2015/04/30/ru-pub-59946, 7 VI 2018.

27 Tamże.
} 
stwierdził, że ich stosunki są zaufane, dobre, a nawet przyjacielskie $e^{28}$, zaś Xi, że łączy ich wspólny charakter ${ }^{29}$. Na pewno lączy ich filozoficzne podejście do polityki: obaj są realistami i chcieliby powrotu potęgi swoich państw. To sprawia, że różnice interesów nie prowadzą do poważnych konfliktów ani do palenia mostów. Ich dobre relacje przekładają się na wymowne rezultaty ekonomiczne, takie jak warta 12 mld dolarów pożyczka dla Jamał LNG od chińskich banków, sprzedaż działki SIBUR Sinopecowi i umowa w sprawie pożyczki na budowę szybkiej kolei Moskwa-Kazań bez gwarancji państwowych (to ostatnie wciąż nie zostało zrealizowane) ${ }^{30}$. Wymienione transakcje potwierdzają, że osobiste relacje między Władimirem Putinem a Xi Jinpingiem wzmacniają stosunki rosyjsko-chińskie przez gwarancję „stabilności kadrowej”31.

Chiny stały się także ważnym czynnikiem dla najbliższego otoczenia Władimira Putina, co można zaobserwować na poziomie instytucjonalnym i osobistym. Jeśli chodzi o ten pierwszy, to do czasu rosyjskiego zwrotu ku Azji (lata 2011-2014) instytucjonalne związki z Chinami były luźne, koordynowane przez międzyrządową komisję przygotowującą spotkania premierów oraz komisję do spraw dialogu w kwestiach energetycznych. Po 2011 r. stworzono nową komisję międzyrządową, której rosyjskim współprzewodniczącym został wicepremier Igor Szuwałow, ważny doradca Putina do spraw ekonomicznych; jego komisja stała się jednostką negocjującą wielkie projekty bilateralne. Dodatkowo Putin mianował swojego przyjaciela Giennadija Timczenkę przewodniczącym rosyjsko-chińskiej rady biznesowej ${ }^{32}$. Oprócz tego istnieje międzyrządowa komisja do spraw „dialogu energetycznego” oraz kolejna, do spraw kulturalnych, pod przewodnictwem Olgi Gołodiec; tak duża ilość ciał administracyjnych nie sprzyja sprawności, gdyż powoduje niejasny podział kompetencji i biurokratyczne opóźnienia ${ }^{33}$. Pośród aktorów grupowych największym zwolennikiem zacieśniania stosunków z Chinami, mimo problemów w negocjowaniu warunków umów, pozostał sektor energetyczny uznający relacje z Chinami za szansę na rozwój. Podobnie ciepły stosunek do Chin ma administracja rządowa, której podoba się model społeczno-polityczny tego kraju. Armia pozostaje ambiwalentna, podczas gdy służby specjalne i inne służby mundurowe należą do najbardziej zdystansowanych względem współpracy z Chinami;

28 Ответыь на вопросы журналистов, Kremlin.ru, 5 IX 2016, [online] http://kremlin.ru/events/presi $\mathrm{dent} /$ news/52834, 25 V 2018.

29 Путин и Си Цзиньпин сошлись характерами, Столетие, 24 III 2013, [online] http://www.stoletie. ru/na_pervuiu_polosu/putin_i_si_czinpin_soshlis_kharakterami_746.htm, 25 V 2018.

30 A. Gabuev, Putin-Xi Friendship Driving Russia-China Ties, Carnegie Moscow Center, 3 VI 2016, [online] http://carnegie.ru/2016/06/03/putin-xi-friendship-driving-russia-china-ties-pub-63733, $25 \mathrm{~V}$ 2018; Ради дружбы Путина и Си Цзиньпина, Inosmi.ru, 17 III 2016, [online] https://inosmi.ru/ politic/20160317/235747288.html, 25 V 2018.

31 D. Trienin, From Greater Europe to Greater Asia? The Sino-Russian Entente, Carnegie Moscow Center, 9 IV 2015, [online] https://carnegieendowment.org/files/CP_Trenin_To_Asia_WEB_2015Eng. pdf, 25 V 2018.

32 A. Gabuev, Friends with Benefits? Russian-Chinese Relations After the Ukrainian Crisis, Carnegie Moscow Center, 29 VI 2016, [online] http://carnegie.ru/2016/06/29/friends-with-benefits-russian-chinese-relations-after-ukraine-crisis-pub-63953, 25 V 2018.

33 «Китайцьь понимают, что... 
nie posiadają jednak decydującego głosu - ten bez wątpienia należy do zwolenników współpracy, gdyż wśród elit przeważa przekonanie, że Chiny nie zagrażają reżimowi rosyjskiemu ${ }^{34}$.

Omawiając jednostkowych zwolenników rozwoju relacji z Chinami, należy wskazać długoletniego ambasadora w Chinach, Igora Rogaczowa (zmarł w 2005 r.), zwanego patriarchą relacji rosyjsko-chińskich ${ }^{35}$. Od początku XXI w. zwolennikami (i beneficjentami) zbliżenia z Pekinem w najbliższym kręgu Putina byli Igor Sieczin, jeden z jego najważniejszych współpracowników, odpowiedzialny za sektor energii i osobiście zaangażowany w rozwój relacji z Chinami; Siergiej Iwanow (do sierpnia 2016 r.) i Dmitrij Rogozin, związani z sektorem wojenno-przemysłowym ${ }^{36}$. Kolejnymi zwolennikami zbliżenia z Pekinem w bezpośrednim otoczeniu Putina są (wspomniany wyżej) Giennadij Timczenko ${ }^{37}$ oraz Jurij Trutniew, specjalny wysłannik prezydenta na rosyjski Daleki Wschód ${ }^{38}$. Chiny zrobiły wiele, by tych ludzi nastawić do siebie życzliwie. Jak pisze Aleksander Gabujew, Chiny uczynity zwrot ku przyjaciotom Putina: będąc niechętne do znaczącego inwestowania w Rosji z powodu spowolnienia gospodarczego w Chinach w 2015 r., Zhongnanhai (siedziba Komunistycznej Partii Chin w Pekinie) dało osobom z najbliższego kręgu Putina korzystne pożyczki i mite uktady energetyczne po to, by sprawić, żeby klika Putina pozostata zadowolona i patrzaca na Wschód ${ }^{39}$.

Na niższym poziomie rosyjskiej administracji opinia o Chinach jest jednak znacznie mniej przychylna. Mimo odczuwalnej sympatii do chińskiego modelu rosyjscy urzędnicy wyższego szczebla (poza najbliższym otoczeniem Putina) - nie mówiąc o tych średniego i niskiego szczebla - wciąż traktują Zachód jako punkt odniesienia. Chociaż Rosjanie są cyniczni odnośnie moralności i intencji zachodnich przywódców, pozostaja wrażliwi na zachodnie wptywy [...] nie pozostawiając suchej nitki na Zachodzie, wysytaja swoje dzieci na europejskie i amerykańskie uniwersytety, kupuja nieruchomości w Londynie, trzymaja swoje oszczędności $w$ bankach zachodnich i sądza się w brytyjskich sadach. Czyniac to, przyznaja niedostownie, że Zachód jest najlepszy ${ }^{40}$.

Przeciętny rosyjski urzędnik wyższego szczebla mało wie o Chinach, myśląc czasem, że to biedny i zacofany kraj: jedzie tam raz na rok, podpisuje jakieś dokumenty, ale ci, z którymi ma do czynienia po chińskiej stronie, sa dla niego catkowicie obcy, zaś ich kraj niegodny uwagi; nawet przyjaźń Putina z Xi nie jest dla czynowników wyższego szczebla dobrą nowiną: jeśli nasz przywódca jest zaprzyjaźniony z Chińczykami, to

34 M. Kaczmarski, Russia-China Relations... 43; tenże, Russia-China Relations and the West, Working Paper Series, Center for Transatlantic Relations, III 2017, [online] https://transatlanticrelations.org/ wp-content/uploads/2017/03/RBSG-Ostpolitik-2-track-2-book-Kaczmarski-final_website2.pdf, $25 \mathrm{~V} 2018$.

А.В. Аукин, От нормализащии к..., s. 318.

36 M. Kaczmarski, Russia-China Relations..., s. 43.

37 I. Bond, Russia and China. Partners of Choice and Necessity?, CER Report 2016, 8 XII 2016, [online] http://www.cer.eu/sites/default/files/rpt_russia_china_8dec16_0.pdf, 25 V 2018. «Китайщьь понимаюот, что...

39 A. Gabuev, China's Pivot...

Bobo Lo, Russia and The New..., s. 198 i 225. 
jest to znak dla catej elity, że trzeba prześcigać się w przyjaźni z Chińczykami, a to jest $t_{\text {trudne }}{ }^{41}$. Dominacja Zachodu nie ogranicza się tylko do elit politycznych: rosyjscy naukowcy pracuja na zachodnich uniwersytetach i w tamtejszych instytutach badawczych, informatycy i programiści jada do Doliny Krzemowej; rosyjskie firmy szukaja zachodniej technologii i know-how; a rosyjska klasa średnia uznaje się za część lepszej, europejskiej cywilizacji [...] pomimo rozwoju Azji, rosyjski drenaż mózgów ptynie na Zachód, nie do Chin czy Indii ${ }^{42}$. I nie zamierza wracać. Rosyjski laureat Nagrody Nobla w dziedzinie fizyki, Andriej Gejm, na pytanie, co skłoniłoby go do powrotu do Rosji, odparł: reinkarnacja ${ }^{43}$.

\section{ROSYJSKI ZWROT KU CHINOM}

Percepcja Chin jako kraju niezagrażającego Rosji doprowadziła Kreml do zaprzestania prób równoważenia Chin i wybrania bliższej współpracy na jeszcze bardziej nierównych (chińskich) warunkach. Najlepiej widać to w sektorach energii i sprzedaży broni oraz w sinocentrycznej polityce Rosji w Azji Wschodniej i na rosyjskim Dalekim Wschodzie, a także we współpracy w Azji Środkowej i w przyłączeniu się do projektu Nowego Jedwabnego Szlaku. Te wszystkie elementy sprawiły, że ogłaszany kilkukrotnie (2011, 2012, 2014 r.) „rosyjski zwrot ku Azji” stał się tak naprawdę „zwrotem ku Chinom".

Pierwszym tego przykładem jest współpraca energetyczna. Rosja przez długi czas starała się nie popadać w zależność od Chin i równoważyć ich wpływy przez kontakty z innymi krajami azjatyckimi. Było to szczególnie widoczne przy okazji zmiany rosyjskiego nastawienia do Chin w kwestii ropociągu WSTO oraz gazociągu. WSTO był tego pierwszym przykładem. Rosja na początku XXI w. kształtowała relacje z Chinami i Japonią przy pomocy WSTO (chcąc uzyskać od obu tych państw jak najlepsze warunki, Rosja podawała sprzeczne informacje w sprawie trasy ropociągu), jednak po kryzysie światowym 2008 r. zmuszona została do pogodzenia się z rzeczywistością i wybrania chińskiej odnogi do Daqingu w zamian za chińskie kredyty ${ }^{44}$. Ta decyzja sprawiła, że udało się zbudować obie nitki WSTO, lecz wynik transakcji okazał się korzystny zwłaszcza dla Chin (które zdołały wymusić większą przepustowość ropociągu i jeszcze niższą cenę: $15 \mathrm{mln}$ ton ropy na 25 lat za 270 mld dolarów), podobnie jak okres trwania kontraktu. Zdecydowana większość surowca transportowanego całym ropociągiem płynie do Chin, a po 2013 r. Rosja dostarczyła Chinom dodatkowe

41 «Китайщы понимают, что...

42 Bobo Lo, Russia and The New..., s. 140 i 198.

43 Nobel Winners Tell Why Russia Lacks Allure, „The Moscow Times” 2010, 21 X, [online] https://themoscowtimes.com/news/nobel-winners-tell-why-russia-lacks-allure-2360, 26 V 2018.

44 Соглашение о принципах строительства и эксплуатачии нефтепровода « Сковородино - граница с КНР» между Китайской начиональной нефтегазовой корпорачией и ОАО АК «Транснефть», Совместное коммюнике по итогам тринадцатой регулярной встречи глав правительств КНР и РФ, 29 X 2008, [online] russian.china.org.cn, 26 V 2018. 
$10 \mathrm{mln}$ ton ropy kazachskim ropociągiem. Do 2020 r. Rosja dostarczy Chinom łącznie $56 \mathrm{mln}$ ton ropy (około $20 \%$ całego rosyjskiego eksportu) ${ }^{45}$. Już w $2017 \mathrm{r}$. Rosja stała się największym dostarczycielem ropy do Chin, prześcigając nawet Arabię Saudyjską ${ }^{46}$. Rosja przystała na warunki Chin z przyczyn geopolitycznych, jak przyznał sam Putin: po to, by utrzymywać nacisk na Unię Europejską ${ }^{47}$ (straszak dywersyfikacji dostaw).

Podobna sytuacja miała miejsce w przypadku gazociągu Siła Syberii. Przez ponad dekadę Rosja i Chiny nie były w stanie porozumieć się w sprawie gazociągu rosyjsko-chińskiego (Rosjanie nie chcieli zgodzić się na niską cenę Chin, a ponadto negocjowali głównie po to, by wywrzeć presję na Europę, zaś Chińczycy zbudowali w międzyczasie gazociąg z Turkmenistanu i mogli pozwolić sobie na niespieszne rozmowy ze stroną rosyjską), jednakże kwestie polityczne ponownie przesądziły sprawę. W obliczu konfliktu ukraińskiego Putin podczas wizyty w Szanghaju w maju 2014 r. zdecydował (osobiście ${ }^{48}$ o podpisaniu 30-letniego kontraktu na 38 mld metrów sześciennych gazu rocznie ze złóż w Jakucjii ${ }^{49}$, prawdopodobnie za 346 dolarów za 1000 metrów sześciennych (co było ceną korzystną dla strony chińskiej) ${ }^{50}$. W tym celu powstaje gazociąg Siła Syberii, który ma osiągnąć długość 4000 kilometrów oraz przepustowość $61 \mathrm{mld}$ metrów sześciennych rocznie ${ }^{51}$. Obecnie, po opóźnieniach budowy, szacuje się, że gaz popłynie do Chin około 2021-2022 r.

Kontrakt ten był wielkim sukcesem Chińczyków, gdyż zapewnił im długoterminowe dostawy taniego gazu transportowanego drogą lądową. Z perspektywy Rosji rachunek zysków i strat jest mniej oczywisty: $\mathrm{z}$ jednej strony wkrótce po podpisaniu kontraktu ceny ropy znacząco się obniżyły (co wpłynęło na ceny gazu), więc przyjęta cena, patrząc z dzisiejszej perspektywy, nie była tak niekorzystna dla strony rosyjskiej ${ }^{52} . \mathrm{Z}$ drugiej strony - gazociąg ten raczej nie stanie się „gazowym oknem do Azji”, jak chcieliby Rosjanie $^{53}$, gdyż zmonopolizuje dostawy rosyjskiego gazu do Chin i na długi czas uzależni

45 M. Kaczmarski, Russia-China Relations..., s. 59.

46 Chen Aizhu, Meng Meng, Russia beats Saudi Arabia as China's Top Crude Oil Supplier in 2016, Reuters, 23 I 2017, [online] http://www.reuters.com/article/us-china-economy-trade-crude-idUSKBN1570VJ, 25 V 2018.

47 Владимир Путин выпустил восточносибирскую нефть в море (Vladimir Putin Released Eastern Siberian Oil into Sea), „Ведомости” 2009, 29 XII.

48 Bobo Lo, Russia and The New..., s. 9.

49 S. Kardaś, Gazowe „partnerstwo wschodnie”. Kontrakt Gazpromu i CNPC na dostawy gazu do Chin, Komentarze OSW, 16 VI 2014, [online] https://www.osw.waw.pl/pl/publikacje/komentarze-osw/2014-06-16/gazowe-partnerstwo-wschodnie-kontrakt-gazpromu-i-cnpc-na, $25 \mathrm{~V}$ 2016; «Газпром» и Китай подписали Меморандум о взаимопонимании по поставкам газа по «восточному» маршруту, „Газпром. Официальный сайт” 2013, 22 III.

50 S. Kardaś, Gazowe „partnerstwo wschodnie”...

51 «Сила Сибири» Якутский и Иркутский центры газодобъюии, Oil Capital.ru.

52 D. Trienin, From Greater Europe...

53 Россия прорубила „газовое окно” в Азию - благодаря, но не назло Европе, „РИА Новости” 2014, $21 \mathrm{~V}$. 
Rosję od chińskiego rynku (czego oznaką jest m.in. porzucenie przez Gazprom planów budowy terminalu LNG we Władywostoku $)^{54}$. Porozumienie gazowe w praktyce pogłębia asymetrię gospodarczą Rosji wobec Chin, czyniąc z Rosji energetycznego wasala $C_{\text {Cin }}{ }^{55}$. Tym samym - zamiast próbować równoważyć wpływy Chin, Rosja postawiła na pogłębioną współpracę z nimi na chińskich warunkach.

Kolejnym przykładem zmiany postawy Rosji wobec Chin jest sprzedaż broni. Od początku lat 90. XX w. sprzedaż broni była ważnym (momentami najważniejszym) czynnikiem wpływającym na relacje rosyjsko-chińskie. Na początku XXI w. Rosja przestała sprzedawać Chinom najnowocześniejszą technologię wojskową, widząc, że ta jest kopiowana i następnie odsprzedawana innym państwom, co szkodzi interesom komercyjnym Rosji. Dlatego też Rosja, mimo ciągłej sprzedaży broni Chinom, nie oferowała Pekinowi najnowocześniejszego sprzętu (podczas gdy np. Indiom i Wietnamowi - tak). Na skutek konfliktu ukraińskiego, upadku rosyjskiej gospodarki i sankcji zachodnich Moskwa zmieniła jednak zdanie i w kwietniu 2015 r. sprzedała Chinom 6 batalionów systemów antyrakietowych S-400 56 ; zaś w listopadzie 2015 - 24 myśliwce $\mathrm{Su}-35^{57}$. Były również inne, choć drugorzędne, powody rosyjskiej zmiany nastawienia: dywersyfikacja eksporterów przez tradycyjnych odbiorców rosyjskiej broni takich jak Indie, przekonanie, że Chiny rozwijają swój przemysł wojskowy na tyle szybko, iż wkrótce nie będą zainteresowane kupnem rosyjskiego sprzętu, oraz fakt, że produkcja Su-35 miała się wkrótce zakończyćc ${ }^{58}$. Wszystkie te przyczyny spowodowały, że Rosja zrezygnowała ze swojej dotychczasowej polityki niesprzedawania najbardziej zaawansowanego sprzętu Chinom, co doprowadziło do zmiany modelu, w którym to Indie otrzymywały lepsze uzbrojenie od Chin (obecnie oba te państwa otrzymują takie samo - Indie również kupiły Su-35 i S-400). Sprzedaż Su-35 pokazała rosnące zaufanie do Chin wśród rosyjskiego establishmentu i potwierdziła sinocentrycznq orientacje rosyjskiej polityki zagranicznej w Azji ${ }^{59}$.

Sinocentryczne nastawienie Rosji widać jeszcze wyraźniej w polityce względem dwóch, powiązanych ze sobą obszarów: rosyjskiego Dalekiego Wschodu (RDW) oraz Azji Wschodniej (Azji-Pacyfik). Rosja od rozpadu ZSRR snuła plany rozwoju trudnego obszaru RDW (zapóźnionego gospodarczo ${ }^{60} \mathrm{i}$ antychińskiego społecznie ${ }^{61}$ ) przy pomocy innych niż Chiny azjatyckich partnerów (Japonia, Korea Południowa, Tajwan),

54 M. Kaczmarski, Russia-China Relations... s. 64, 67.

55 S. Kardaś, Gazowe „partnerstwo wschodnie”...

56 Yu Bin, All Still Quiet in the East, „Comparative Connections” 2015, vol. 17, nr 1, [online] http:// cc.csis.org/2015/05/still-quiet-east/, 26 V 2018.

57 Russia Inks Contract with China on Su-35 Deliveries, TASS. Russian News Agency, 19 XI 2015, [online] http://tass.ru/en/defense/837662, 22 VI 2016.

58 Yu Bin, Tales of Different „Pivots”, „Comparative Connections” 2013, vol. 14, nr 3, [online] http:// cc.csis.org/2013/01/tales-different-pivots/, 26 V 2018.

59 M. Kaczmarski, Russia-China Relations... s. 74.

60 Symbolu ztego zarzadzania, korupcji i porzucenia, zob. Bobo Lo, Russia and The New..., s. 224.

${ }_{61}$ To właśnie tam narodziły się w latach 90. XX w. niedorzeczne teorie o chińskiej ekspansji migracyj$n e j$, które ucichły już w Rosji i na Zachodzie (za to w Polsce niestety wciąż nie); kwestię tę omawiam 
którzy jednak nie byli zbytnio zainteresowani inwestowaniem w ten mało gościnny biznesowo obszar. W drugiej dekadzie XXI w. władze Rosji pogodziły się z realiami i zaakceptowały fakt, że jedynie współpraca z Chinami może wpłynąć na poprawę sytuacji w regionie RDW. Moskwa - by użyć słów Putina - postanowita ztapać chiński wiatr ${ }^{62}$ i rozwinąć RDW dzięki kapitałowi chińskiemu ${ }^{63}$. Stworzono Plan Rozwoju Rosyjskiego Dalekiego Wschodu, z udziałem ponad 250 mieszanych spółek, w takich obszarach, jak infrastruktura, drogi, kolej, eksploatacja surowców i inne ${ }^{64}$. Dodatkowo we Władywostoku i 15 okolicznych okręgach morskich w 2015 r. uruchomiono specjalną strefę ekonomiczną.

Niestety program rozwoju nie okazał się sukcesem Rosji, gdyż zrealizowano tylko kilka z licznych planowanych inwestycji ${ }^{65}$. Chińskie inwestycje w RDW dzielą się na dwa typy: są to albo projekty surowcowe, które wzmacniają pozycję Rosji jako dodatku surowcowego do Chin, albo póllegalne i nielegalne sposoby na dostarczanie chińskiej produkcji na rosyjski rynek ${ }^{66}$. W przypadku obu zyski, zamiast wspierać gospodarkę centralną, lądują na prywatnych kontach ${ }^{67}$. Sami Chińczycy nie spieszą się z masowym inwestowaniem w RDW w innych sektorach, gdyż współpraca gospodarcza z Rosją ma znaczenie tylko dla jednej (sic!) prowincji chińskiej - pogranicznego Heilongjiangu (nawet pozostałe prowincje dawnej Mandżurii, czyli Jilin i Liaoning, nie mają żywotnego interesu w handlu z Rosją) ${ }^{68}$. Brak chińskiego zaangażowania frustruje Rosjan, czego najlepszym dowodem były słowa Jurija Trutniewa, specjalnego przedstawiciela Prezydenta Federacji Rosyjskiej na RDW, który publicznie zapytał Chińczyków, dlaczego chcą inwestować w Angoli, a nie w Rosji (czy Angola naprawdę ma lepszy klimat inwestycyjny niz Rosja?! - pytał $)^{69}$. Mimo zawodu spowodowanego brakiem oczekiwanych wyników Rosja wciąż ma nadzieję, że chińskie inwestycje nadejdą, gdyż uznaje,

w swojej monografii: M. Lubina, Niedźwiedź w cieniu smoka. Rosja-Chiny 1991-2014, Kraków 2014, s. $173-182$.

62 ВАадимир Путин, Россия и менятощийся мир, Московские новости 27 II 2012, [online], http:// www.mn.ru/politics/7873, 18 VII 2010.

63 Программа сотрудниества между регионами Аальнего Востока и Восточной Сибири РФ и Северо-Востока КНР (2009-2018 годъ), Политическое образование.ru, 18 VII 2010.

64 Tamże.

65 В. Кулешев і in., О некоторых аспектах совершенствования российско-китайского межрегионального сотрудничества, „Проблемы Аальнего Востока” 2010, nr 6, s. 67; А. Аарин, Несколько замечании о возрождении Аальнего Востока России на фоне возрожденмия китайской нащии, [w:] Азиатско-тихоокеанское сотрудничество и место России в региональном развитии, Москва 2014, s. 19.

Ф. Аукьянов, Поворот на восток, SVOP, 15 II 2010.

67 А.В. Аукин, Россия и Китай сегодня и завтра, [w:] Россия и Китай: четьре века взаимодействия. История, современное состояние и перспективы развития российско-китайских отношений, Москва 2013, s. 649-668. в российско-китайских отномениях, [w:] tатże, s. 485-499.

69 Yu Bin, Into the Syrian Storm. Between Alliance and Alignment, „Comparative Connections” 2015, vol. 17, nr 3, [online] http://cc.csis.org/2016/01/syrian-storm-alliance-alignment/, 26 V 2018. 
poniekąd słusznie, że ekonomicznie tylko Chiny są w stanie zdynamizować rozwój rosyjskiego Dalekiego Wschodu. Warto zwrócić uwagę na zmianę nastawienia lokalnych władz we Władywostoku, Chabarowsku i innych obszarach RDW, które jeszcze 20 lat temu głosiły teorie o migracyjnej ekspansji Chin, a 10 lat temu zgłaszały chęć współpracy z każdym, byle nie z Chinami, zaś obecnie mają nadzieję na chińskie inwestycje. Wraz z sinocentryczną centralną polityką Moskwy metamorfoza ta ilustruje, jak Rosja stopniowo porzucała ambicje równoważenia Chin na rzecz nadziei na skorzystanie $\mathrm{z}$ ich wzrostu.

Równie wyraźnie widać to w obszarze polityki azjatyckiej (dalekowschodniej) Rosji, czyli w Azji-Pacyfik. Od początku XXI w. Rosja starała się równoważyć Chiny przez koncepcję ,azjatyckiego koncertu mocarstw”, „różnorodności strategicznej” i większego multilateralizmu ${ }^{70}$. Wszystkie te próby zakończyły się częściową lub pełną porażką na skutek obiektywnych czynników: niemożności porozumienia się z Japonią (nie doszło do przełomu mimo ocieplenia relacji za czasów rządów Shinzō Abe), braku szans na intensyfikację relacji z Indiami (poza sferą sprzedaży broni), niechęci innych państw do koncepcji „azjatyckiego koncertu mocarstw” (a także zaangażowania w nią Rosji), nieumiejętności funkcjonowania przez Rosję w azjatyckich warunkach (niezdarne próby udowadniania, że Rosja podziela „sposób ASEAN” jawnie kłóciły się z działaniami Rosji na terenie postradzieckim - w Gruzji i na Ukrainie), dominującej orientacji europejskiej w polityce rosyjskiej oraz rozdźwięku między słowami a czynami w azjatyckiej polityce Rosji ${ }^{11}$. To wszystko sprawiło, że Moskwa w drugiej dekadzie XXI w. porzuciła próby równoważenia Chin i wybrała jeszcze wyraźniejsze zbliżenie (gazociąg Siła Syberii), unikanie konfliktu (kwestia koreańska) ${ }^{72}$ oraz poparcie chińskiego stanowiska w - najistotniejszej dla regionu - sprawie konfliktu o wyspy na Morzu Południowochińskim $^{73}$. Tym samym Rosja de facto (choć po cichu) poddała się i przestała walczyć o stałe miejsce na dalekowschodniej szachownicy, zadowalając się statusem "młodszego partnera” Chin. To doprowadziło do tego, że mimo deklaratywnego „zwrotu ku Azji” znaczenie Rosji w regionie Azji-Pacyfik w drugiej dekadzie XXI w. zmalało w porównaniu do poprzedniej dekady (choć i tak jest większe niż w okresie jelcynowskim). Ostatnim obszarem, w którym Rosja pogodziła się z pozycją Chin, jest Azja Środkowa. Ongiś dominująca pozycja Rosji w regionie została zakwestionowana przez interwencję amerykańską w Afganistanie w 2001 r. Moskwa zwróciła się więc ku Pekinowi,

70 Bobo Lo, The Axis..., s. 115-132; A. Acharya, A Concert of Asia?, „Survival” 1999, vol. 41, nr 3, s. 89.

${ }^{71}$ Bobo Lo, Russia and the New..., s. 132-165. Sposób ASEAN (ASEAN Way) to potoczne określenie na styl prowadzenia polityki państw ASEAN opierający się na Pięciu Zasadach Pokojowego Współistnienia.

72 Po okresie chwilowego zbliżenia z Phenianem w 2014 i 2015 r. Rosja obecnie w pełni popiera stanowisko chińskie.

73 Moskwa do 2016 r. dystansowała się od konfliktu, następnie jednak przyjęła stanowisko chińskie. Pierwszym krokiem była wypowiedź ministra Ławrowa (zob. Интервью Министра иностранньцх дел России С.В.Ааврова СМИ Монголии, Японии и КНР в преддверии визитов в эти страньи, Москва, 12 IV 2016, [online] www.mid.ru, 25 V 2018), którą potwierdził potem sam Putin (zob. Ответы на вопросы журналистов). Było to interpretowane jako odwdzięczenie się Rosji za (częściowe) wsparcie chińskie w kwestii ukraińskiej. 
by wspólnie wyrugować zachodnie wpływy z Azji Środkowej, co w dużej mierze się powiodło. Chiny wszakże pozostały w regionie, rozwijając współpracę energetyczną (co usunęło monopol Rosji) oraz gospodarczą (stały się głównymi partnerami handlowymi państw Azji Środkowej) $)^{74}$, a także ogłosily ambitny projekt Nowego Jedwabnego Szlaku (Pasa i Szlaku) ${ }^{75}$, który - jeśli zostanie zrealizowany - dodatkowo wzmocni chińskie wpływy. W odpowiedzi na to Rosja postanowiła reintegrować Azję Środkową za pomocą projektu Unii Euroazjatyckiej, do którego przystąpiły na razie Kazachstan i Kirgistan. Ewidentna sprzeczność wizji rosyjskich i chińskich projektów integracyjnych oraz coraz ambitniejsza polityka Chin w Azji Środkowej sprawiły, że wielu przewidywało rozpoczęcie „nowej Wielkiej Gry”, tym razem między Rosją a Chinami ${ }^{76}$. Nic takiego jednak nie nastąpiło. Rosja i Chiny zdołały uniknąć konfrontacji i pogodzić swoje interesy, dzieląc się wpływami w regionie ${ }^{77}$ : Moskwa utrzymała swoją dominację w sferze politycznej i bezpieczeństwa, zaś Chiny w gospodarce. Moskwa toleruje ten stan, gdyż obecność chińska pomaga w utrzymywaniu regionu z dala od wpływów zachodnich i spełnia tym samym podstawowy cel polityki rosyjskiej. Dlatego właśnie Rosja przestała blokować chińską ekspansję w Azji Środkowej i postanowiła przyłączyć się do projektu Nowego Jedwabnego Szlaku, tytułując się mianem mostu między Azja a Europa, bez którego realizacja całej inicjatywy byłaby niemożliwa ${ }^{78}$. Także z tej przyczyny Rosja i Chiny próbują połączyć Nowy Jedwabny Szlak z Unią Euroazjatycką, na razie nieskutecznie ${ }^{79}$, co jednak - zdaniem chińskich badaczy - jest nieistotne wobec faktu politycznego porozumienia o niewchodzeniu sobie $\mathrm{w} d r o g \varepsilon^{80}$. Porozumienie w Azji Środkowej doprowadziło do usunięcia regionu z listy problemów we wzajemnych stosunkach ${ }^{81}$ i nie zaszkodziło stabilnym relacjom rosyjsko-chińskim.

$74 \quad$ K. Kozłowski, Państwo Środka a Nowy Jedwabny Szlak. Proradziecka Azja Centralna i Xinjiang w polityce CHRL, Torun 2011, s. 180-208.

75 President Xi Jinping Delivers Important Speech and Proposes to Build a Silk Road Economic Belt with Central Asian Countries, Ministry of Foreign Affairs of the People's Republic of China, 7 IX 2013, [online] http://www.fmprc.gov.cn/mfa_eng/topics_665678/xjpfwzysiesgjtfhshzzfh_665686/ t1076334.shtml, 26 V 2018.

76 M.E. Ahrari, J. Beal, The New Great Game in Muslim Central Asia, Honolulu 2002; R.A. Mullerson, Central Asia. A Chessboard and Player in the New Great Game, London 2014; A. Cooley, Great Games, Local Rules. The New Great Power Contest in Central Asia, Oxford 2012.

77 M. Kaczmarski, Russia-China Relations..., s. 92; A. Gabuev, Friends with Benefits?...

78 M. Kaczmarski, W. Rodkiewicz, Russia's Greater Eurasia and China's New Silk Road. Adaptation Instead of Competition, Komentarze OSW 21 VII 2016, [online] https://www.osw.waw.pl/en/publikacje/osw-commentary/2016-07-21/russias-greater-eurasia-and-chinas-new-silk-road-adaptation, $26 \mathrm{~V}$ 2018.

79 Yu Bin, Politics of „Reluctant Allies”...

80 Zhao Huasheng, Zhong'e guanxi zhibian le ma?, „Pengbo” 2016, 10 VII, za: M. Duchâtel, China and Russia. Towards an Alliance Treaty?, [w:] China and Russia. Gaming the West?, [online] http://www. ecfr.eu/page/-/ECFR_195_-_CHINA_AND_RUSSIA_GAMING_THE_WEST_(002).pdf, 26 V 2018.

81 M. Kaczmarski, Russia-China Relations..., s. 100-101. 


\section{ALEKSANDER NEWSKI NOWYM ROSYJSKIM WZOREM}

Z powyżej przytoczonych przykładów wynika wyraźnie, że Rosja porzuciła próby balansowania Chin i wybrała przyłączenie się do ich rozwoju. Kreml uznaje tę sytuację za tymczasową konieczność, do której trzeba się dostosować, by pozostać w grze o status światowego mocarstwa. Moskwa uznała, że to Zachód jest największym zagrożeniem dla istnienia reżimu i wielkomocarstwowych ambicji Kremla, stąd prochiński wybór był niejako naturalną konsekwencją tego stanowiska. Szukając wzorców z przeszłości dla uzasadnienia takiej polityki, kremlowscy decydenci przywołali postać XIII-wiecznego ruskiego księcia Aleksandra Newskiego.

Już w 2011 r. Putin nazwał Newskiego świetlanym przykładem służby Ojczyźnie, który mimo bardzo trudnej sytuacji Rusi rozpoczą ruch ku zjednoczeniu kraju². Od tego momentu rozpoczęło się przywoływanie dziedzictwa Newskiego w kontekście współczesnej polityki zagranicznej, które trwa do dzisis ${ }^{83}$, razem z dyskusją dotyczącą najazdu mongolskiego (tatarskiego) w XIII w., który zaczyna w Rosji być przedstawiany znacznie mniej negatywnie niż do tej pory ${ }^{84}$. W lipcu 2014 r., w momencie intensyfikacji kryzysu ukraińskiego, Dmitrij Trienin, który zdaniem wielu pełni funkcję eksperta prezentującego Zachodowi rosyjski punkt widzenia w sposób dla Zachodu akceptowalny, przyrównał działania Rosji wprost do polityki Newskiego, który skutecznie odbit zagrożenie zachodniej inwazji, pozostając lojalny wobec mongolskich chanów ${ }^{85}$. W najbardziej wyrazisty sposób ideę współczesnej polityki rosyjskiej w nawiązaniu do Newskiego sformułował minister spraw zagranicznych Rosji Siergiej Ławrow podczas wykładu w 2015 r. Stwierdził wówczas, że okres mongolski ma ogromne znacznie dla podkreślenia niezależności państwa rosyjskiego w Eurazji, zaś historia nie potwierdza popularnego przekonania, że Rosja zawsze znajdowata się na peryferiach Europy $i$ byta politycznym outsiderem Europy ${ }^{86}$. Według Ławrowa Newski wybrat tymczasowe podporzadkowanie sie Ztotej Ordzie, by utrzymać rosyjskie prawo do decydowaniu o samym sobie pomimo prób zachodniej Europy, by podporządkować sobie rosyjskie ziemie i pozbawić Rosjan ich tożsamości; dzięki Newskiemu Ruś ugięta się, lecz nie ztamata pod ciężkim jarzmem mongolskim izdotata przetrwać tę trudna próbe jako jedno państwo, które później byto uznawane zarówno przez Zachód, jak i Wschód jako sukcesor Imperium Bizantyjskiego; obecne elity rosyjskie zaś mają tę mądra i dalekowzroczna politykę w genach ${ }^{87}$.

82 Путин привел Александра Невского как пример патриота, Gazeta.ru, 23 V 2011.

83 Иекторий СВОП: Почему Россия никак неможет попасть в Европу; Александр Разуваев: У России есть два достойныцх союзника, Vzglyad.ru, 10 VII 2015.

84 Татаро-монгольского ига не было, считают историки, Ria Novosti, 14 X 2010, [online] https://ria. ru/history_comments/20101014/285598296.html, 26 V 2018.

85 D. Trienin, China's Victory in Ukraine, „Project Syndicate” 2014, 31 VII.

86 Статья Министра иностранных дел России С.В.Ааврова «Историческал перспектива внешней политики России», опубликованная в журнале «Россия в глобальной политике», 3 III 2016, [online] www.mid.ru, $26 \mathrm{~V} 2018$.

87 Tamże. 
Przekaz tej narracji jest całkowicie jasny. Rosja zamiast być outsiderem na Zachodzie, wybiera tymczasową akceptację dominacji potężnego sąsiada na Wschodzie, dzięki czemu zdoła wytrzymać trudne czasy, nie ugnie się i w przyszłości powróci jako mocarstwo. W kontekście współczesnych relacji rosyjsko-chińskich komunikat ten sugeruje, że Rosja nie widzi obecnie możliwości zmiany systemu, dostosowuje się więc do przewagi chińskiej, uznaje to jednak za stan tymczasowy i wyczekuje możliwości jego zmiany.

Wbrew rosyjskim nadziejom okazji do tej zmiany nie umożliwiła prezydentura Donalda Trumpa, od której Moskwa wiele oczekiwała. Republikański kandydat, wbrew swojej partii i większości establishmentu amerykańskiego, wyrażał się ciepło o Rosji i Putinie. Te deklaracje w połączeniu z wpływami rosyjskimi w sztabie Trumpa i rosyjskim internetowym mataczeniem przy wyborach, które wpłynęło na korzyść Trumpa ${ }^{88}$, dawały Moskwie nadzieje na nowe rozdanie w relacjach z USA i - choć nie mówiono tego wprost - na zakończenie stanu uzależnienia od Chin. Rosji marzył się nowy koncert mocarstw, w którym otrzyma wolną rękę na obszarze byłego ZSRR. To dlatego pojawiły się głosy o kolejnej zmianie ról w trójkącie USA-Rosja- Chiny czy nawet o odwróconym manewrze Nixona ${ }^{89}$ (te głosy były również popularne w Polsce $)^{90}$.

Nic takiego jednak nie nastąpiło. Establishment amerykański skutecznie zablokował działania Trumpa (i tak skoncentrowanego na polityce wewnętrznej), zaś antyrosyjski nastrój panujący w USA uświadomił prezydentowi elektowi, że dokonując zbliżenia z Rosją, ma mało do zyskania, a dużo do stracenia. Te wnioski spowodowały odejście Trumpa od zauważalnej w kampanii wyborczej prorosyjskiej retoryki na rzecz mniej przychylnego kursu wobec Moskwy. Warto zauważyć, że Moskwa, wyczekując ustępstw ze strony Trumpa, nie uczyniła niczego, co mogłoby pogorszyć jej relacje z Chinami (tak jak to miało miejsce na przykład w 2001 r., gdy Putin od razu przyłączył się do antyterrorystycznej koalicji Busha, nie informując Pekinu i zapominając o wspólnej z Chinami opozycji wobec amerykańskiej dominacji). Rosyjscy politycy, w tym sam Putin, byli bardzo ostrożni, nie chcąc popsuć stosunków z Chinami ${ }^{91}$. Mieli rację - nadzieje związane z Trumpem nie ziściły się, lecz Rosja nie ucierpiała na tym, zachowując status quo. Pomimo oczekiwań Rosja za czasów prezydentury Trumpa nie osiągnęła korzystnej dla siebie zmiany ${ }^{92}$. Zgodnie z założeniami polityki wzorowanej na

88 M. Menkiszak, Rosja wybiera Trumpa. Moskwa wobec wyborów prezydenckich w USA, Komentarze OSW, 9 XI 2016, [online] https://www.osw.waw.pl/pl/publikacje/komentarze-osw/2016-11-09/ rosja-wybiera-trumpa-moskwa-wobec-wyborow-prezydenckich-w-usa, 26 V 2018.

89 S. Tisdall, Donald Trump Attempting to Play Nixon's „China Card” in Reverse, „The Guardian” 2016, 12 XII.

90 J. Bartosiak, Pacyfik i Eurazja. O wojnie, Warszawa 2016, s. 450-630.

91 Yu Bin, The Dawn of a Brave Trump World, „Comparative Connections” 2017, vol. 18, nr 3, [online] http://cc.csis.org/2017/01/dawn-brave-trump-world/, 26 V 2018.

92 Szerzej omawiam ten temat w swojej najnowszej monografii o relacjach rosyjsko-chińskich, M. Lubina, Russia and China. A Political Marriage of Convenience - Successful and Stable, Opladen-BerlinToronto 2017, s. 155-160. 
działaniach Aleksandra Newskiego będzie zatem wciąż współpracowała z Chinami na chińskich warunkach, cierpliwie czekając, aż nadejdzie moment sprzyjający emancypacji międzynarodowej.

\section{PODSUMOWANIE. MIĘDZY REALIZMEM A KONSTRUKTYWIZMEM W STOSUNKACH ROSYJSKO-CHIŃSKICH}

Biorąc pod uwagę praktykę rosyjskiej polityki, wydawać by się mogło, że realistyczne zapatrywania tego kraju są niezagrożone. Przypadek relacji rosyjsko-chińskich pokazuje jednak, że pogląd ten nie jest do końca prawdziwy. Dlaczego bowiem Rosja - stosująca realizm polityczny w czystej formie - zachowała się w stosunku do Chin w sposób tak nierealistyczny? Zgodnie z założeniami realizmu Moskwa powinna dążyć do balansowania potęgi Chin $\mathrm{i}, \mathrm{w}$ istocie, taką politykę starano się wdrażać w pierwszej dekadzie XXI w. Począwszy od światowego kryzysu ekonomicznego w 2008 r., a szczególnie po konflikcie ukraińskim w 2014 r., Rosja wybrała jednak zbliżenie z Chinami na chińskich warunkach, godząc się na ropociąg i gazociąg do Chin, podporządkowując im swoją politykę na rosyjskim Dalekim Wschodzie i w Azji-Pacyfik oraz przyłączając się do projektu Nowego Jedwabnego Szlaku. Innymi słowy, Moskwa wobec Chin zastosowała klasyczny bandwagoning.

Szkoła konstruktywistyczna stosunków rosyjsko-chińskich pokazuje, że zbliżenie z Chinami wyniknęło z ich percepcji przez obecną elitę kremlowską. W. Putin i jego przyboczni uznali, że Chiny nie zagrażają Rosji ani, co chyba ważniejsze, reżimowi i postanowili wytrzymać presję zachodnią, równocześnie wchodząc $\mathrm{w}$ ścisłą zależność względem Pekinu. Mimo to realizm nie znikną z myślenia rosyjskich elit politycznych, które uzasadniły „zwrot ku Chinom” nie tylko korzyściami geopolitycznymi i ekonomicznymi, lecz również powołały się na przykład Aleksandra Newskiego, który uznał tymczasowe podporządkowanie Mongołom za konieczność, „mądrość etapu”, jak powiedziałby klasyk. Świadczy to o tym, że elity rosyjskie mają świadomość, iż podporządkowanie się Chinom jest tylko środkiem do celu, którym niezmiennie pozostaje zdobycie pozycji światowego mocarstwa. Moskwa liczyła na to, że prezydentura Donalda Trumpa polepszy pozycję Rosji na arenie międzynarodowej, jednak nadzieje te nie ziściły się - co zweryfikowało tezy osób patrzących na relacje rosyjsko-chińskie tylko przez pryzmat geopolityczny - i utrzymało dotychczasową dynamikę w trójkącie USA-Chiny-Rosja. Z powyższych rozważań można wywnioskować, że zarówno realizm, jak i konstruktywizm są bardzo potrzebne w badaniu relacji rosyjsko-chińskich, gdyż oferują odmienne spojrzenia, które często są komplementarne.

\section{BIBLIOGRAFIA}

Acharya A., A Concert of Asia?, „Survival” 1999, vol. 41, nr 3.

Ahrari M.E., Beal J., The New Great Game in Muslim Central Asia, Honolulu 2002. 
Aizhu Chen, Meng Meng, Russia Beats Saudi Arabia as China's Top Crude Oil Supplier in 2016, Reuters, 23 I 2017, [online] http://www.reuters.com/article/us-china-economytrade-crude-idUSKBN1570VJ.

Bartosiak J., Pacyfik i Eurazja. O wojnie, Warszawa 2016.

Bin Yu, China-Russia, All Still Quiet in the East, „Comparative Connections” 2015, vol. 17, nr 1, [online] http://cc.csis.org/2015/05/still-quiet-east.

Bin Yu, Into the Syrian Storm. Between Alliance and Alignment, "Comparative Connections” 2015, vol. 17, nr 3, [online] http://cc.csis.org/2016/01/syrian-storm-alliance-alignment/.

Bin Yu, Politics of „Reluctant Allies”, „Comparative Connections” 2016, vol. 18, nr 2, [online] http://cc.csis.org/2016/09/politics-reluctant-allies/.

Bin Yu, The Dawn of a Brave Trump World, „Comparative Connections” 2017, vol. 18, nr 3, [online] http://cc.csis.org/2017/01/dawn-brave-trump-world/.

Bond I., Russia and China. Partners of Choice and Necessity?, CER Report 2016, 8 XII 2016, [online] http://www.cer.eu/sites/default/files/rpt_russia_china_8dec16_0.pdf.

Cooley A., Great Games, Local Rules. The New Great Power Contest in Central Asia, Oxford 2012.

Dingli Shen, Russian Cooperation with China is Tactical, Not Strategic, „Global Times” 2016, 27 VI.

Gabuev A., China and Russia. Friends With Strategic Benefits, Carnegie Moscow Center, 7 IV 2017, [online] http://carnegie.ru/2017/04/07/china-and-russia-friends-withstrategic-benefits-pub-68628.

Gabuev A., China's Pivot to Putin's Friends, „Foreign Affairs” 2016, 25 VI.

Gabuev A., Friends with Benefits? Russian-Chinese Relations After the Ukrainian Crisis, Carnegie Moscow Center, 29 VI 2016, [online] http://carnegie.ru/2016/06/29/ friends-with-benefits-russian-chinese-relations-after-ukraine-crisis-pub-63953.

Gabuev A., Putin-Xi Friendship Driving Russia-China Ties, Carnegie Moscow Center, 3 VI 2016, [online] http://carnegie.ru/2016/06/03/putin-xi-friendship-driving-russia-chinaties-pub-63733.

Huang Yufan, Q. \& A.: Yan Xuetong Urges China to Adopt a More Assertive Foreign Policy, „The New York Times" 2016, 9 II.

Huasheng Zhao, Zhong'e guanxi zhibian le ma?, „Pengbo” 2016, 10 VII.

Hsiung J.C., A Re-Appraisal of Abrahamic Values and Neorealist IR theory. From a Confucian-Asian Perspective, [w:] China and International Relations. The Chinese View and the Contribution of Wang Gungwu, London 2010.

Jakobsen L. i in., China's Energy and Security Relations with Russia. Hopes, Frustrations and Uncertainties, „SIPRI Policy Paper” 2011, nr 29.

Johnston A.I., Cultural Realism. Strategic Culture and Grand Strategy in Chinese History, Princeton 1995.

Kaczmarski M., Rosja na rozdrożu. Polityka zagraniczna Wtadimira Putina, Warszawa 2006.

Kaczmarski M., Russia-China Relations in the Post-Crisis International Order, London 2015.

Kaczmarski M., Rodkiewicz W., Russia's Greater Eurasia and China's New Silk Road. Adaptation Instead of Competition, Komentarze OSW 21 VII 2016, [online] https://www.osw. waw.pl/en/publikacje/osw-commentary/2016-07-21/russias-greater-eurasia-and-chinasnew-silk-road-adaptation. 
Kardaś S., Gazowe „partnerstwo wschodnie”. Kontrakt Gazpromu i CNPC na dostawy gazu do Chin, Komentarze OSW, 16 VI 2014, [online] https://www.osw.waw.pl/pl/publikacje/komentarze-osw/2014-06-16/gazowe-partnerstwo-wschodnie-kontrakt-gazpromui-cnpc-na.

Kozłowski K., Państwo Środka a Nowy Jedwabny Szlak. Proradziecka Azja Centralna i Xinjiang w polityce CHRL, Toruń 2011.

Lo Bobo, Russia and The New World Disorder, London 2015.

Lo Bobo, The Axis of Convenience. Moscow, Beijing, and the New Geopolitics, London-New York 2008.

Lubina M., Niedźwiedź w cieniu smoka. Rosja-Chiny 1991-2014, Kraków 2014.

Lubina M., Russia and China. A Political Marriage of Convenience - Stable and Successful, Opladen-Berlin-Toronto 2017

Menkiszak M., Rosja wybiera Trumpa. Moskwa wobec wyborów prezydenckich w USA, Komentarze OSW, 9 XI 2016, [online] https://www.osw.waw.pl/pl/publikacje/komentarze-osw/2016-11-09/rosja-wybiera-trumpa-moskwa-wobec-wyborow-prezydenckich-w-usa.

Mullerson R.A., Central Asia. A Chessboard and Player in the New Great Game, London 2014.

Nation R.C., Russia in East Asia. Aspirations and Limitations, [w:] Russia's Prospects in Asia, red.

S. Blank, Strategic Studies Institute 2010.

Nobel Winners Tell Why Russia Lacks Allure, „The Moscow Times” 2010, 21 X, [online] https://themoscowtimes.com/news/nobel-winners-tell-why-russia-lacks-allure-2360.

Pei Minxin, China and Russia: Best Frenemies Forever?, „Fortune” 2013, 28 III.

President Xi Jinping Delivers Important Speech and Proposes to Build a Silk Road Economic Belt with Central Asian Countries, Ministry of Foreign Affairs of the People's Republic of China, 7 IX 2013, [online] http://www.fmprc.gov.cn/mfa_eng/topics_665678/xjpfwzysiesgjtfhshzzfh_665686/t1076334.shtml.

Qin Yaqing on Rules vs Relations, Drinking Coffee and Tea, and a Chinese Approach to Global Governance „Theory Talk \#45”, [online] https://www.files.ethz.ch/isn/155106/Theory \%20Talk45_Yaqing.pdf.

Rapprochement or Rivalry? Russia-China Relations in a Changing Asia, red. S.W. Garnett, Washington D.C. 2000.

Rozman G., The Sino-Russian Challenge to the World Order. National Identities, Bilateral Relations, and East Versus West in the 2010s, Stanford 2014.

Russia Inks Contract with China on Su-35 Deliveries, TASS. Russian News Agency, 19 XI 2015, [online] http://tass.ru/en/defense/837662.

The Future of China-Russia Relations, red. J. Ballacqua, Kentucky 2010.

Tisdall S., Donald Trump Attempting to Play Nixon's „China Card” in Reverse, „The Guardian” 2016, 12 XII.

Trienin D., China's Victory in Ukraine, „Project Syndicate” 2014, 31 VII.

Trienin D., From Greater Europe to Greater Asia? The Sino-Russian Entente, Carnegie Moscow Center 2015, 9 IV 2015, [online] https://carnegieendowment.org/files/CP_Trenin_To_ Asia_WEB_2015Eng.pdf.

Wilson J.L., Strategic Partners. Russian-Chinese Relations in the Post-Soviet Era, London 2004. Xuetong Yan, Ancient Chinese Thought, Modern Chinese Power, Princeton 2011. 
Xuetong Yan, Shijie quanli de zhuanyi. Zhengzhi lingdao yu zhanluejingzheng (The Transition of World Power. Political Leadership and Strategic Competition), Beijing 2015.

Yan Xuetong Urges China to Adopt a More Assertive Foreign Policy, „The New York Times” 2016, 9 II.

Ying Fu, How China Sees Russia. Beijing and Moscow Are Close, but Not Allies, „Foreign Policy” 2015, 14 XII.

Yongdian Zheng, Preface, [w:] China and International Relations. The Chinese View and the Contribution of Wang Gungwu, London 2010.

Владимир Путин вылустил восточносибирскую нефть в море (Vladimir Putin Released Eastern Siberian Oil into Sea), „Ведомости” 2009, 29 XII.

«Газпром» и Китай подписали Меморандум о ваимопонимании по поставкам газа по «восточному» маршруту, „Газпром. Официацьный сайт” 2013, 22 III.

Аацышен В.Г., Аарин В.А., Романова Г.Н., Замок с гранииы снят. Приграничныц регионьь в российско-китайских отношениях, [w:] Россия и Китай: четьре века взаимодействия. История, современное состояние и перспективы развития российско-китайских отношений, red. А.В. Аукина, Москва 2013.

Интерввю Министра иностранньц дел России С.В.Ааврова СМИ Монголии, Японии и КНР в преддверии визитов в эти страны, Москва, 12 IV 2016, [online] www.mid.ru.

«Китайцы понимают, ито Россия деградирует из-за коррупции и неэффективного управления», Lenta.ru, 30 IV 2015 [online], www.lenta.ru.

Кумешев B. і іп., О некоторьхх аспектах совершенствования российско-китайского межрегионального сотрудничества, „Проблемы Аамьнего Востока” 2010, $\mathrm{nr} 6$.

Аарин А., Несколько замечании о возрождении Аальнего Востока России на фоне возрожденмия китайской начии, [w:] Азиатско-тихоокеанское сотрудниество и место России в региональном развитии, Москва 2014.

Иекторий СВОП: Почему Россия никак не может попасть в Европу; Александр Разуваев: У России есть два достойньх союзника, Vzglyad.ru, 10 VII 2015.

Аукин А.В., От нормализачии к стратегическому партнерству. Россия и Китай после распада СССР, [w:] Россия и Китай: четьре века взаимодействия. История, современное состояние и перспективы развития российско-китайских отношений, Москва 2013.

Аукин А.В., Россия и Китай сегодня и завтра, [w:] Россия и Китай: четьре века взаимодействия. История, современное состояние и перспективы развития российско-китайских отношений, Москва 2013.

Иукьянов Ф., Поворот на восток, SVOP, 15 II 2010.

Ответь на вопросьцжуналистов, Kremlin.ru, 5 IX 2016, [online] http://kremlin.ru/events/ president/news/52834, $25 \mathrm{~V} 2018$.

Программа сотрудниества между регионами Аальнего Востока и Восточной Сибири РФ и Северо-Востока КНР (2009-2018 годъ), Политическое образование.ru, 18 VII 2010.

Путин Владимир, Россия и меняюшийся мир, Московские новости 27 II 2012, [online], http://www.mn.ru/politics/7873.

Путин и Си Цзиньпин сошлись характерами, Столетие, 24 III 2013, [online] http://www. stoletie.ru/na_pervuiu_polosu/putin_i_si_czinpin_soshlis_kharakterami_746.htm.

Путин привел Александра Невского как пример патриота, Gazeta.ru, 23 V 2011. 
Ради дружбъь Путина и Си Цзиньпина, Inosmi.ru, 17 III 2016, [online] https://inosmi.ru/ politic/20160317/235747288.html.

Россия прорубила „газовое окно” в Азию - благодаря, но не назло Европе, „РИА Новости” 2014, $21 \mathrm{~V}$.

Совместнал деклараиия Российской Федеращии и Китайской Народной Республики, 2 XII 2002, [online] www.mid.ru.

«Сила Сибири» Якутский и Иркутский центры газодобьюи, Oil Capital.ru.

Совместнал декларащия Российской Федеращии и Китайской Народной Республики, [w:] Сборник российско-китайских договоров 1949-1999, Москва 2000.

Соглашение о принщипах строительства и эксплуатащии нефтепровода «Сковородино гранииа с КНР» между Китайской начиональной нефтегазовой корпорачией и ОАО АК «Транснефть», Совместное коммюнике по итогам тринадцатой регулярной встречи глав правительств КНР и РФ, 29 X 2008, [online] russian.china.org.cn.

Статья Министра иностранных дел России С.В.Ааврова «Историческал перспектива внешней политики России», опубликованная в журнале «Россия в глобальной политикe», 3 III 2016, [online] www.mid.ru.

Tатаро-монгольского ига не было, считают историки, Ria Novosti, 14 X 2010, [online] https://ria.ru/history_comments/20101014/285598296.html.

Тренин А., Верньєе друзья? Как Россия и Китай воспринимают друг друга, Carnegie Moscow Center, 1 VI 2012, s. 20, [online] https://carnegieendowment.org/files/CER_TreninRuss_ web.pdf.

Dr Michał LUBINA jest adiunktem w Instytucie Bliskiego i Dalekiego Wschodu UJ oraz autorem czterech książek, w tym Niedźwiedź w cieniu smoka. Rosja-Chiny 1991-2014 (Kraków 2014), pierwszej monografii o współczesnych relacjach rosyjsko-chińskich w języku polskim. Zajmuje się badaniem stosunków rosyjsko-chińskich oraz współczesnej Birmy. 